\title{
Vitamin D Deficiency Among Female University Students (18 to 25 years) in Spring
}

\author{
Kadın Üniversite Öğrencilerinde Hastalık Riski Düzeyinde Vitamin D Eksikliği
}

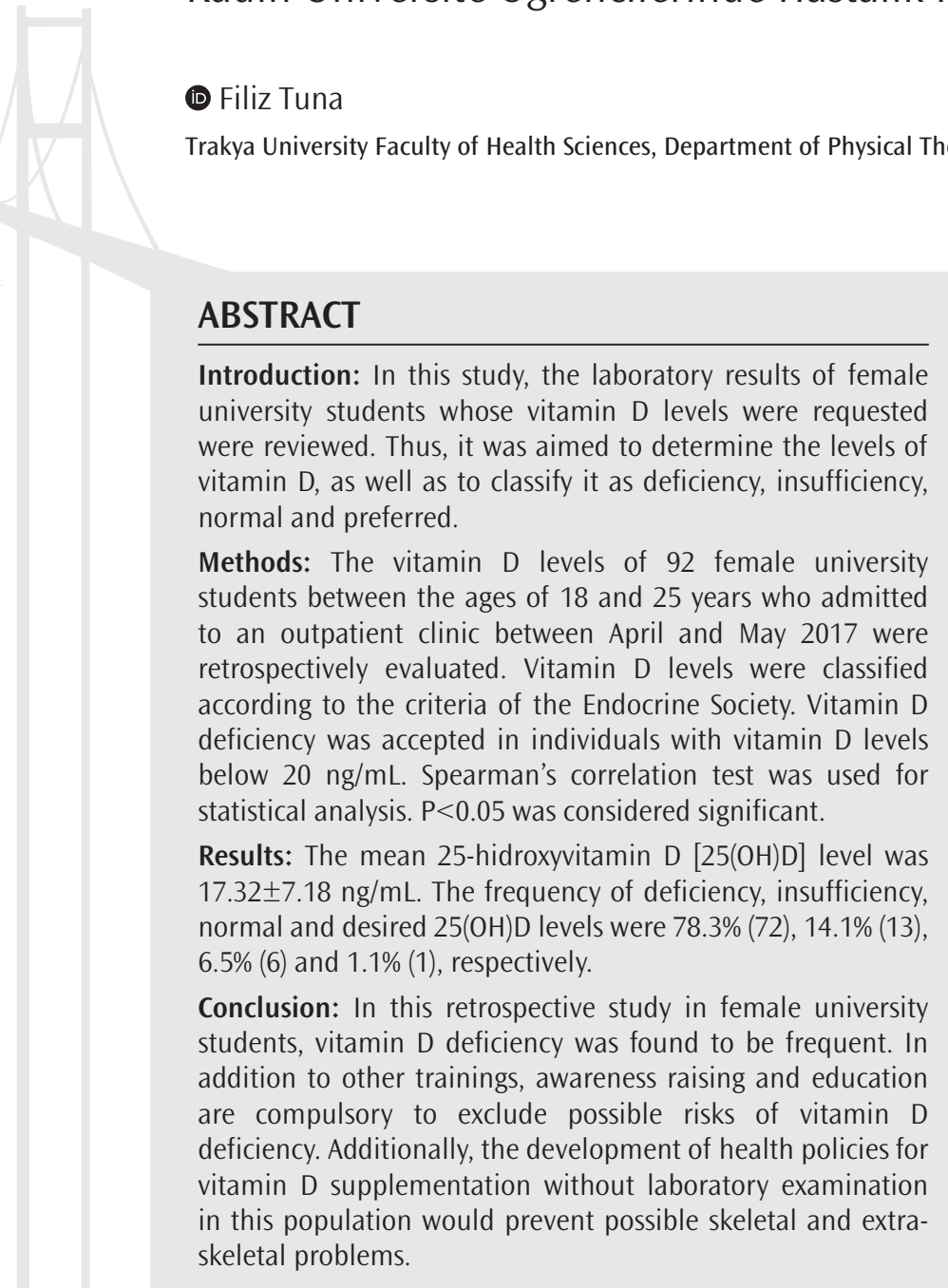

Keywords: 25(OH)D vitamin, insufficiency, adolescents öz

Amaç: $\mathrm{Bu}$ araştırmada, vitamin $\mathrm{D}$ düzeyi istenen kadın üniversite öğrencilerinin laboratuvar sonuçları gözden geçirilmiştir. Böylece vitamin D düzeylerini belirlemek, ayrıca eksiklik, yetersizlik, normal ve tercih edilen düzey olarak sınıflandırmak amaçlanmıştır.

Yöntemler: Bu araştırmaya Nisan ve Mayıs 2017 tarihleri arasında polikliniğe başvuran 18-25 yaş arası 92 kadın üniversite öğrencilerinin vitamin D düzeyleri üzerinde retrospektif olarak yapıldı. Vitamin D düzeyleri Endokrin Topluluğu'nun önerilerine göre sınıflandırıldı. Vitamin D düzeyi $20 \mathrm{ng} / \mathrm{mL}$ 'nin altında olan bireylerde vitamin D eksikliği varlığı kabul edildi. İstatistiksel analiz için Spearman korelasyon testi kullanıldı. $\mathrm{P}<0,05$ anlamlı olarak kabul edildi.

Bulgular: 25-hidroksivitamin D [25(OH)D] seviyesi ortalama $17,32 \pm 7,18 \mathrm{ng} / \mathrm{mL}$ idi. Eksik, yetersiz, normal ve arzu edilen 25(OH)D düzeyi oranları sırasıyla $\% 78,3$ (72), \%14,1 (13), \%6,5 (6) ve \%1,1 (1) saptandı.

Sonuç: Kadın üniversite öğrencilerinde yürüttüğümüz bu retrospektif çalışmada; hastalık olușturma riski düzeyinde olan vitamin D eksikliğinin sık olduğu görüldü. Diğer eğitimlerin yanı sıra D vitamini eksikliğinin olası risklerini dışlamak için bilinçlendirme ve eğitim zorunludur. Ayrıca, bu popülasyonda laboratuvar incelemesi olmaksızın gerekli D vitamini takviyesi için sağlık politikalarının geliștirilmesi olası iskelet ve iskelet dıșı problemleri önleyecektir.

Anahtar Kelimeler: 25(OH)D vitamini, yetersizlik, gençler

\section{Introduction}

Vitamin D, a hormone called "Pro-survival Molecule" due to its role in the immune system and cell life, is also necessary for the prevention of type 2 diabetes and obesity, which are important problems of current era $(1,2)$. Optimal levels of vitamin D are indispensable for substantial effects on many systems in sensitive populations such as pregnant women, nursing women, children, adolescents, and elder individuals as well as in all stages of human life $(3,4)$. It contributes to the prevention of depression in adolescents and increase in cardiovascular capacity in young adults $(5,6)$.

Vitamin D level below $20 \mathrm{ng} / \mathrm{mL}$ is defined as deficiency by Endocrine Society (ES). Its deficiency is associated with increased risk of cancer, especially colorectal $(7,8)$. Hereditary or acquired diseases (e.g., tumorinduced osteomalacia, hyperparathyroidism, granulomatous diseases 
and lymphoma) and insufficiency in organs (e.g., liver, kidney and skin) may decrease vitamin D levels. In addition, using sun cream, pigmentation or aging on the skin affects the synthesis of vitamin D. Also, gastrointestinal diseases adversely effect vitamin D absorption and obesity leads to an increase in its deposition (9). The use of certain drugs such as immunosuppressants, steroids and anticonvulsants also leads to the destruction of vitamin $D(10,11)$. However, there is no enough data on vitamin D status and recommendations for asymptomatic, adolescent female university students who do not have any disease or use drugs that affect vitamin D metabolism (12). While vitamin D deficiency is mainly considered to be a predisposing factor to many diseases, neither adolescent female nor male students are included in the risk group in terms of low vitamin D status and are evaluated in daily practice (12).

In this study, we aimed to determine and classify vitamin D levels as deficiency, insufficiency, normal and preferred in female university students.

\section{Methods}

This cross-sectional, retrospective and descriptive study was carried out with the approval of the Local Ethics Committee of the Faculty of Health Sciences of Trakya University (TÜTF-BAEK 2017/335). Vitamin D levels of female university students between the ages of 18 and 25 years who admitted to Physical Medicine and Rehabilitation Department of Trakya University Hospital between April and May 2017 were examined. Data of students with no systemic or chronic disease, no drug use, and no history of disease that would affect vitamin D metabolism were included. Exclusion criteria were as follows: male gender, drug use, serum 25-hidroxyvitamin D [25(OH)D] level obtained by a method other than electrochemiluminescence method (Beckman Coulter UniCel DxI $600)$, and the presence of a known disease. Each student was contacted by phone and interviewed about the style of clothing. Written consent was obtained from each participant. The clothing style was recorded as veiled or unveiled. Serum $25(\mathrm{OH}) \mathrm{D}$ levels were classified as deficiency (below $20 \mathrm{ng} / \mathrm{mL}$ ), insufficiency $(21-29 \mathrm{ng} / \mathrm{mL})$, normal $(30-39 \mathrm{ng} / \mathrm{mL}$ ) and preferred (40-60 ng/mL) levels according to most frequently used method by ES (13).

\section{Statistical Analysis}

Statistical evaluations were performed using IBM SPSS version 20.0 (IBM Corporation, Armonk, NY, USA). Descriptive statistical methods (frequency, percentage, mean, standard deviation) were used to assess the study data. The relationships between variables were assessed using Spearman's rho correlation test. The significance limit for all statistics was selected as $p<0.05$. Kolmogorov Smirnov test was used to check whether the data were normally distributed. Mann-Whitney $U$ test was used to compare the mean $25(\mathrm{OH}) \mathrm{D}$ levels between groups when the data were abnormally distributed. Two-sample Kolmogorov Smirnov Z test was used to make inter-group (unveiled vs veiled) comparisons of 25(OH)D classifications.

\section{Power Analysis}

The post-hoc power of this study was calculated as $100 \%$ based on $25(\mathrm{OH}) \mathrm{D}$ levels between unveiled and veiled groups (18.25 vs 13.19) with a standard deviation of 1.67 , and with an alpha level of $5 \%$.

\section{Results}

Data of 92 female university students were reached. Mean age, height, weight, and body mass index (BMI) of the students were shown in Table 1. The mean 25(OH)D level was $17.32 \pm 7.18 \mathrm{ng} / \mathrm{mL}$. According to ES, 25(OH) D levels were below the normal range in $92.4 \%$ (85) participants. The frequency of (all participants with) deficiency, insufficiency, normal and preferred 25(OH)D levels were $78.3 \%$ (72), 14.1\% (13), 6.5\% (6) and 1.1\% (1), respectively. The distribution of participants according to clothing style (unveiled and veiled) were $81.5 \%$ (75) and 18.5\% (17), respectively. There was no statistically significant difference in the distribution of the 25(OH)D Classification groups among the clothing style groups (Table 2). The mean 25(OH)D levels among unveiled and veiled participants were $18.25 \pm 0.80$ and $13.19 \pm 1.67 \mathrm{ng} / \mathrm{mL}$, respectively. There were a statistically significant difference between the groups in terms of mean $25(\mathrm{OH}) \mathrm{D}$ levels and negative correlation between $25(\mathrm{OH}) \mathrm{D}$ concentrations and veiled dressing style $(r=-0.275, p=0.008)$ (Table 3).

\section{Discussion}

Although veiling is largely accepted as a predisposing factor for vitamin D insufficiency, both the unveiled females in our study and in countries with sufficient sunlight in previous studies did not have desired vitamin D levels $(14,15)$.

\begin{tabular}{|c|c|c|c|c|c|}
\hline & $\mathrm{n}$ & Minimum & Maximum & Mean & $\begin{array}{l}\text { Standard } \\
\text { deviation }\end{array}$ \\
\hline Age (years) & 92 & 18 & 24 & 20.28 & 1.65 \\
\hline Weight (kg) & 92 & 42.00 & 77.00 & 56.83 & 6.37 \\
\hline Height (m) & 92 & 1.50 & 1.78 & 1.64 & 0.05 \\
\hline $\mathrm{BMI}\left(\mathrm{kg} / \mathrm{m}^{2}\right)$ & 92 & 16.85 & 27.64 & 21.02 & 2.00 \\
\hline $25(\mathrm{OH}) \mathrm{D}(\mathrm{ng} / \mathrm{mL})$ & 92 & 6.77 & 48.74 & 17.32 & 7.18 \\
\hline
\end{tabular}

BMI: body mass index, 25(OH)D: 25-hidroxyvitamin D

Table 2. Distribution of 25(OH)D classifications among groups

\begin{tabular}{|c|c|c|c|c|c|}
\hline \multirow{2}{*}{\multicolumn{2}{|c|}{$\begin{array}{l}\text { Groups } \\
\text { Unveiled } \\
n=75\end{array}$}} & \multicolumn{4}{|c|}{ n (\% within groups) } \\
\hline & & $\begin{array}{l}\text { Veiled } \\
n=17\end{array}$ & $p$ value & $\begin{array}{l}\text { Total } \\
n=92\end{array}$ & \\
\hline \multirow{4}{*}{$\begin{array}{l}25(\mathrm{OH}) \mathrm{D} \\
\text { classification }\end{array}$} & Deficiency & $57(76.0)$ & 15 (88.2) & \multirow{4}{*}{0.986} & 72 (78.3) \\
\hline & Insufficiency & $12(16.0)$ & $1(5.9)$ & & $13(14.1)$ \\
\hline & Normal & $5(6.7)$ & $1(5.9)$ & & $6(6.5)$ \\
\hline & Preferred & $1(1.3)$ & $0(0)$ & & $1(1.1)$ \\
\hline
\end{tabular}

Two-sample Kolmogorov Smirnov Z test, 25(OH)D: 25-hidroxyvitamin D

\begin{tabular}{|c|c|c|c|c|c|c|}
\hline $\begin{array}{l}\text { Clothing } \\
\text { style }\end{array}$ & $\mathbf{n}$ & $\begin{array}{l}\text { Minimum- } \\
\text { maximum }\end{array}$ & Mean & $\begin{array}{l}\text { Standard } \\
\text { deviation }\end{array}$ & $95 \% \mathrm{Cl}$ & $\begin{array}{l}p \\
\text { value }\end{array}$ \\
\hline Unveiled & 75 & $7.96-48.74$ & 18.25 & 0.80 & $16.65-19.85$ & \multirow{2}{*}{$<0.001$} \\
\hline Veiled & 17 & $6.77-34.60$ & 13.19 & 1.67 & $9.66-16.72$ & \\
\hline
\end{tabular}

Cl: confidence interval, Mann-Whitney U test, 25(OH)D: 25-hidroxyvitamin D 
The adverse effect of veiling on vitamin D status has led some researchers to assume the possibility of musculoskeletal complaints and low bone mineral density in veiled female with traditional Islamic type of dressing (16). Guzel et al. (16) reported significantly lower serum $25(\mathrm{OH}) \mathrm{D}$ levels with a mean of $33.1 \pm 16 \mathrm{ng} / \mathrm{mL}$ in the veiled women compared with the unveiled, but none of the veiled women had vitamin D insufficiency. Budak et al. (17) reported that there was a statistically significant difference between two groups of female students with different clothing style and the veiled group had vitamin D deficiency with a mean of $6.09 \pm 4.7 \mathrm{ng} / \mathrm{mL}$. Tsur et al. (18) reported vitamin D deficiency in $50-100 \%$ of ultra-Orthodox young males who wore clothing which covers more then $90 \%$ of body. They also found that vitamin D deficiency was strongly associated with the degree of sun exposure. However, some researchers indicates that healthy females, even in countries with enough sunlight, are at risk for osteomalacia due to vitamin D deficiency $(14,15)$. For all these reasons, the female gender in combination with veiling does not suffice for the possibility of vitamin D deficiency. Risks should be assessed comprehensively. In this study, 18.5\% of females (17) had veiling, but $92.4 \%$ of all females (85) had low vitamin D. Faghih et al. (19) showed "alarmingly prevalent" vitamin $D$ insufficiency and deficiency in Iranian students in a crosssectional study including 126 female (51.2\% and 44\%) and 128 male (49.5\% and $48 \%$ ) university students. In our female population, we found that vitamin D deficiency was as high as $78.3 \%$. The frequency of participants with normal and preferred vitamin D were $6.5 \%$ and $1.1 \%$, respectively. Consistent with the literature, $25(\mathrm{OH}) \mathrm{D}$ levels were below $20 \mathrm{ng} / \mathrm{mL}$ in the majority of our participants. Data on vitamin D levels of young adults in our country are limited. The mean 25(OH)D level of 94 young individuals who applied to the hospital was $21.57 \pm 11.41$ $\mathrm{ng} / \mathrm{mL}$ by Uçar et al. (20). Hekimsoy et al. (21) reported that $74.9 \%$ of adults, especially females (78.7\%), living in an urban, off-shore region have $25(\mathrm{OH}) \mathrm{D}$ deficiency. In this study, the reasons for mean $25(\mathrm{OH})$ D levels below the normal are probably due to (a) in young adults, the lowest vitamin D levels are before summer onset. The data of our study group was obtained between April and May, when vitamin D levels are considered to be lowest. More significant differences between the veiled and unveiled female could possibly be shown if we had assessed data of these variables at a time of highest expected seasonal levels, but we have shown significant negative correlation between $25(\mathrm{OH}) \mathrm{D}$ concentrations and veiling even before the start of summer. (b) Edirne where our study was conducted is in the Marmara region of Turkey, latitudes $40^{\circ} 30-42^{\circ} 00$ North and $26^{\circ} 00-27^{\circ} 00$ East. The average maximum temperatures range between $6.5^{\circ} \mathrm{C}$ in winter to $31.7^{\circ} \mathrm{C}$ in summer, with annual average of $19.6{ }^{\circ} \mathrm{C}$ (22). (c) In our study, the data were assessed in a group of students with approximately 9-month training period, during which they resided in Edirne, which is a non-coastal living area. Therefore, we support the view that university students should be considered as a risky group for vitamin D deficiency regardless of their clothing style and gender.

The mean $25(\mathrm{OH}) \mathrm{D}$ level was $17.32 \pm 7.18 \mathrm{ng} / \mathrm{mL}$ in our study. Serum vitamin D levels below $20 \mathrm{ng} / \mathrm{mL}$ affect skeletal health (8). Although the histopathological findings of osteomalacia in stage 1 are missing, intestinal calcium absorption decreases and loss of bone mineral density develops in this stage, named as subclinical osteomalacia. Indeed, the findings are observed when stage 2 is reached. Thus, no new bone loss occurs in stage 3 , but instead histological and clinical findings are clearly identified. For all these reasons, the treatment in the stage with apparent findings does not prevent bone loss. The precautions should be focused in the asymptomatic first stage (23). However, many individuals with subclinical osteomalacia still remain without a laboratory confirmation and the lack of this knowledge leads to delay in taking precautions.

Vitamin D deficiency can contribute to patient burden caused by psychological reasons (depression, schizophrenia), and autoimmune disorders (type 1 diabetes, multiple sclerosis, rheumatoid arthritis), infections, asthma, type 2 diabetes, osteoporosis, osteomalacia and cancer $(1,10)$. On the other hand, vitamin D supplementation is easy, safe and inexpensive (24). Unless vitamin D deficiency is eliminated, individuals are candidates for all these risks independent of deficiency, defined or undefined. However, supplementation is made only in the defined deficiencies. The missing aspect of our study is that we did not investigate parathyroid hormone levels, skin type and eating habits. However, our results are important to create awareness for optimal vitamin $\mathrm{D}$ requirements in this population.

\section{Conclusion}

Our results indicate that vitamin D deficiency is frequently observed in female students. Awareness and training aimed at excluding the possible risks of vitamin D deficiency as well as other trainings are mandatory. Additionally, the development of health policies to provide the necessary vitamin D support in this population without laboratory examination would prevent possible skeletal and extra-skeletal problems.

\section{Acknowledgements}

We are particularly grateful to Prof. Dr. Necdet Süt, who performed the statistical analysis of the study.

Ethics Committee Approval: Trakya University Faculty of Health Sciences Local Ethics Committee (TÜFT-BAEK 2017/335).

Informed Consent: Written consent was obtained from each participant. Peer-review: Externally and internally peer-reviewed.

Financial Disclosure: The author declared that this study has received no financial support.

\section{References}

1. Chirumbolo S, Bjørklund G, Sboarina A, Vella A. The role of vitamin D in the immune system as a pro-survival molecule. Clin Ther 2017; 39: 894-916.

2. Sergeev IN. Vitamin D-Cellular Ca2+ link to obesity and diabetes. J Steroid Biochem Mol Biol 2016; 164: 326-30

3. Reid IR, Bolland MJ, Grey A. Effects of vitamin D supplements on bone mineral density: a systematic review and meta-analysis. The Lancet 2014; 383: 146-55.

4. Wintermeyer E, Ihle C, Ehnert S, Stöckle U, Ochs G, de Zwart P, et al. Crucial role of vitamin D in the musculoskeletal system. Nutrients 2016; 8: 319.

5. Al Asoom LI. Assessment of plasma level of $25(\mathrm{OH}) \mathrm{D}$ and its correlation with cardiorespiratory fitness in young females of Dammam City, KSA. Journal of Taibah University Medical Sciences 2016; 11: 456-63. 
6. Karabel M, Șimșek Ș, Kenan Haspolat Y, Kelekçi S, Karabel D, Tuncel T, et al. The association between depression and vitamin $\mathrm{d}$ and parathyroid hormone levels in adolescents. International Journal of Pediatrics 2016; 4: 1365-72.

7. Mondul AM, Weinstein SJ, Layne TM, Albanes D. Vitamin D and cancer risk and mortality: state of the science, gaps, and challenges. Epidemiol Rev 2017; 39: 28-48.

8. Bouillon R, Van Schoor NM, Gielen E, Boonen S, Mathieu C, Vanderschueren D, et al. Optimal vitamin D status: a critical analysis on the basis of evidencebased medicine. J Clin Endocrinol Metab 2013; 98: E1283-304.

9. Vimaleswaran KS, Berry DJ, Lu C, Tikkanen E, Pilz S, Hiraki LT, et al. Causal relationship between obesity and vitamin D status: bi-directional Mendelian randomization analysis of multiple cohorts. PLoS Med 2013; 10: e1001383.

10. Schwalfenberg G. Not enough vitamin D. Canadian Family Physician 2007; 53: $841-54$

11. Yildiz EP, Poyrazoglu S, Bektas G, Kardelen AD, Aydinli N. Potential risk factors for vitamin D levels in medium-and long-term use of antiepileptic drugs in childhood. Acta Neurol Belg 2017; 117: 447-53.

12. Souberbielle J-C, Courbebaisse M, Cormier C, Pierrot-Deseilligny C, Viard J-P, Jean $G$, et al. When should we measure vitamin D concentration in clinical practice? Scand J Clin Lab Invest Suppl 2012; 243: 129-35.

13. Holick MF, Binkley NC, Bischoff-Ferrari HA, Gordon CM, Hanley DA, Heaney RP, et al. Evaluation, treatment, and prevention of vitamin D deficiency: an Endocrine Society clinical practice guideline. J Clin Endocrinol Metab 2011; 96: 1911-30.

14. Güllü S, Erdoğan MF, Uysal AR, Bașkal N, Kamel AN, Erdoğan G. A Potential Risk for Osteomalacia due to Sociocultural Lyfestyle in Turkish Women. Endocr J 1998; 45: 675-8

15. Alagöl F, Shihadeh $\mathrm{Y}$, Boztepe $\mathrm{H}$, Tanakol R, Yarman S, Azizlerli H, et al. Sunlight exposure and vitamin D deficiency in Turkish women. J Endocrinol Invest 2000; 23: 173-7.
16. Guzel R, Kozanoglu E, Guler-Uysal F, Soyupak S, Sarpel T. Vitamin D status and bone mineral density of veiled and unveiled Turkish women. J Womens Health Gend Based Med 2001; 10: 765-70.

17. Budak N, Çiçek B, Sahin H, Tutus A. Bone mineral density and serum 25-hydroxyvitamin D level: is there any difference according to the dressing style of the female university students. Int J Food Sci Nutr 2004; 55: 569-75.

18. Tsur A, Metzger M, Dresner-Pollak R. Effect of different dress style on vitamin D level in healthy young Orthodox and ultra-Orthodox students in Israel. Osteoporos Int 2011; 22: 2895-8.

19. Faghih S, Abdolahzadeh M, Mohammadi M, Hasanzadeh J. Prevalence of vitamin d deficiency and its related factors among university students in shiraz, iran. Int J Prev Med 2014; 5: 796-9.

20. Uçar F, Taşlıpınar MY, Soydaş AÖ, Özcan N. Ankara etlik ihtisas eğitim ve araștırma hastanesine bașvuran hastalarda 25-OH Vitamin D düzeyleri. Eur J Basic Med Sci 2012; 2: 12-5.

21. Hekimsoy Z, Dinç G, Kafesçiler S, Onur E, Güvenç Y, Pala T, et al. Vitamin D status among adults in the Aegean region of Turkey. BMC Public Health 2010 10: 782 .

22. (cited 2018 20/03/2018). Available from: https://mgm.gov.tr/ veridegerlendirme/il-ve-ilceler-istatistik.aspx?m=EDIRNE.

23. Priemel M, von Domarus C, Klatte TO, Kessler S, Schlie J, Meier S, et al. Bone mineralization defects and vitamin D deficiency: Histomorphometric analysis of iliac crest bone biopsies and circulating 25-hydroxyvitamin D in 675 patients. J Bone Miner Res 2010; 25: 305-12.

24. Kennel KA, Drake MT, Hurley DL, editors. Vitamin D deficiency in adults: when to test and how to treat. Mayo Clinic Proceedings; 2010: Elsevier. 